\title{
Science clubs for 3 to 6-year-olds: Science with joy of learning and achievement
}

\section{Jenni Vartiainen}

Finland's Science Education Centre LUMA, University of Helsinki • jenni.vartiainen@helsinki.fi

\section{Maija Aksela}

Finland's Science Education Centre LUMA, University of Helsinki

\begin{abstract}
Small child has a natural ability to ask, wonder, and explore. In the spring 2013, Finland's Science Education Centre LUMA, operating within University of Helsinki, targeted its traditional Jippo science clubs for the first time for children as young as 3 to 6 years of age. This article discusses the model for the club and experiences from its implementation in the first stage of a design research project. The aims of the developed Pikku-Jipot (Little Jippos) science club model are to train the inquiry, thinking, and discussion skills of small children, and support the comprehensive social and emotional learning (SEL) through the joy of learning and achievement. The science club with six sessions was implemented during the spring 2013 for 3 to 4 and 5 to 6-year-old children. In total, 25 children and their guardians participated in the club activities. The developed model combined science, technology, art, and emotions through stories, inquiry, role-playing, and music. According to the guardians, the goals of the first science club were reached very well. According to the feedback from the children, especially the characters played by the club guides proved to be a rousing model.
\end{abstract}

\section{Background}

Science education has an important role in the upbringing of the professionals and decision-makers of the future. It is as essential in comprehensive and wholesome education as arts and physical education (e.g. Aksela, 2012). Finland's Science Education Centre LUMA has successfully offered different forms of science education (e.g. clubs, camps, science events, and webzines) for children, youth, and families (e.g. Aksela, 2008; Vartiainen \& Aksela, 2012). Science club is one example of motivating learning environment that can arouse and support the child's interest in studying mathematics, natural sciences, and technology (e.g. Aksela, 1998; Aksela \& Mikkola, 1999).

There is a need for new kinds of approaches to arousing and supporting interest towards studying mathematics, natural sciences, and technology from early on. The lack of interest to study natural sciences has been noticed in many countries (e.g. Krapp \& Prenzel, 2011). In Europe, there is a need for more professionals of natural sciences and mathematics but fewer and fewer youth choose to study these subjects (European Commission, 2007). According to international PISA studies, Finnish youth achieve well in natural sciences and mathematics (OECD 2010) but they are not interested in studying these subjects (Arinen \& Karjalainen, 2007).

Children have natural intrinsic motivation to study and learn new skills (e.g. Hidi \& Harackiewicz, 2000). A child as young as two years old can show interest towards a certain 
subject (Hidi \& Ainley, 2002). If it is desired to influence the direction of the child's interest, it should be done before the age of four (Alexander et al. 2011). When given the option, children have the tendency to choose to engage in activities related to their target of interest (Hidi \& Renninger, 2006). The attitudes of the guardians affect the emergence of interest (Chak, 2010). They have an important role in the development of interest, especially with small children (Alexander et al., 2012).

One way to arouse interest is using different physical and virtual learning environments. Science club, for example, can be an informal learning environment. It has been noted that informal learning environments support the children and youth's interest towards natural sciences (National Research Council U.S., 2009). If the child has been provided with the possibility to learn natural sciences in an informal way at pre-school age, it is expected that he or she will be interested in activities involving natural sciences also in the future (Alexander et al., 2012).

\section{Emotions and social and emotional learning}

Social and emotional learning has a central role in the design and implementation of the science club pilot project. The aim is to achieve as much joy of learning and achievement in small children as possible.

According to previous research literature, emotions have a significant role in learning. During the last decade, more and more research has been conducted on the influence of emotions on interest and learning outcomes. The more intense emotions the pupils experience in the learning situation the better the learning outcome (Allen, 2010). The child's interest and motivation to learn can be aroused and altered through emotions. Positive emotions during the learning situation strengthen the intrinsic and extrinsic motivation (Pekrun, 2006).

Social and emotional learning (SEL) refers to the process in which children's social and emotional skills are developed from pre-school to upper secondary school. The effect is better if using the method is started as early as possible (Weare \& Nind, 2011). Social and emotional learning is based on research knowledge, according to which learning is the most fruitful when it happens in an environment where the atmosphere is encouraging and that enables learning that is positively challenging, committing, and meaningful (CASEL).

Through social and emotional learning, the pupil's interest towards natural sciences and mathematics can be increased and the learning outcomes improved (Haynes et al, 2003). With the help of it, the pupil's sosioemotional skills, attitudes towards self and others and social interaction can be developed (Durlak et al. 2011). Social and emotional learning affects the pupil's life on a wide scale by increasing wellbeing and health and decreasing trouble behavior (Weare \& Nind, 2011). 
In social and emotional learning, the pupil-teacher relationship has a key role. Pupils are motivated to learn from a teacher who they respect and appreciate. However, the most important aspect is the well-managed, positive and safe atmosphere in the learning environment. With regard to the learning outcomes, the learning is more effective if the subject is taken into a context that takes into consideration the current knowledge level of the pupil and that has personal and sociocultural significance to him or her (Haynes et al. 2003).

It has been noted that the expectations of adults affect the child's learning. Learning is the most fruitful when the expectations are high enough and the curriculum is in line with the child's knowledge but provides him or her with reachable challenges (Haynes et al. 2003). When the learning outcomes are taken into scrutiny, the supporting attitudes of the guardians can be equally important to the activities in the learning environment (Weare \& Nind, 2011).

Social and emotional learning aims at making the children aware of their own emotions, expressing them and their impacts. The purpose is to train skills on how to react to different situations and how the reaction could be as constructive as possible. The most essential part is the interpretation of other people's thoughts and emotions and recognizing the reasons behind them. It is also important to communicate one's own emotions and expectations in a way that can be interpreted by others. Social and emotional learning aims at increasing awareness of how own decisions and actions influence others. Encouraging into creative problem solving is one feature of social and emotional learning (Durlak et al, 2011). The five competencies of social and emotional learning are:

- $\quad$ self-awareness

- $\quad$ self-management

- $\quad$ social awareness

- relationship skills

- $\quad$ responsible decision making (Durlak et al, 2011).

Through inquiry-based learning, which was employed in the science club pilot project, children can get positive emotional experiences that can last long into their future. It is a pupil-oriented working method that has been used also in Finnish teaching of natural sciences more or less since the 1960s. In inquiry-based learning, pupils study phenomena through small or wider scale inquiry under the guidance of the teacher. The inquiry typically includes hands-on experiments, like in the science club for small children (e.g. Aksela, 2011).

\section{Design research: Developing the science club model}

In design research (eg. Pernaa, 2013), novel research-based, educational innovations are produced as well as information on the design process and the impact of the innovation on 
the set goals. In science club project, the aim is to design research-based model for science education of small children supporting social and emotional learning. This article discusses the first stage of design research: developing a pilot for the science club according to the problem analysis presented in sections 1 and 2.

Developed model for Pikku-Jipot science club offers science education for small children. The science club was targeted for 3 to 4 and 5 to 6-year-olds. The club was held at University of Helsinki's public venue, Think Corner, and the last club session was held at Helsinki Observatory. The children's guardians were welcome to observe the club activities. Photos of the learning environment can be found online at: www.flickr.com/photos/ myscience/ sets/ 72157632595908927/.

The aim of the club is to train the inquiry, thinking, and discussion skills of small children and support comprehensive social and emotional learning. The activities were planned to support especially activity-related emotions, the main focus being on the emotions during the activity (Pekrun, 2006). During Pikku-Jipot science club, the focal element was creating the sense of security that is important to children. From the competencies of social and emotional learning, the emphasis was put on self-awareness, self-management, and relationship skills.

During the club, the sense of security was achieved by repeating certain elements similarly every time. At the beginning and end of each session, the same songs were sung and the number and length of the activities remained the same throughout the club. The six sessions of Pikku-Jipot science club were interlinked by an inspiring fictional frame story. The protagonist of the story, Professor Kuperkeikka from the planet of Voltti gave the children assignments for inquiry. Each session included three stages: motivation, inquiry and sum up. With the help of the story, the children were motivated to explore the themes of the club: colors, density, states of matter, and space through natural sciences, technology, and mathematics. The themes were linked to everyday life and the children's personal experiences and their observations about the surroundings.

A special emotional experience was achieved through the roles of the club guides. Each guide played the role of a certain character that engaged into the world of inquiry with the children. By giving roles to the guides, science education takes the form of a certain kind of play. Playing helps to further create the social and supporting atmosphere that is important to social and emotional learning (Bulunuz, 2012).

There were four kinds of guide roles in Pikku-J ipot science club: Jippo, Fairy, Dino and Pippi. It was Jippo's task to motivate children into upcoming activities, and sum up the results from homework experiments as well as the children's questions and experiences. Fairy, Dino and Pippi guided their own workshops in which the children conducted inquiries related to the particular theme of the session.

Based on inquiry-based learning, the activities in the workshops were planned to support children's own thinking and observations. There were no step-by-step 
introductions to complete the assignments. The aim was to activate the children through discussion to set the questions and bring out their own ideas on how to solve them. In the workshops, the children worked in small groups of four so that guiding the discussion and encouraging them to create their ideas would be as fruitful as possible.

At the end of each session, the children got a homework inquiry that they could do with their parent or guardian. Each child had their own inquiry notebook that included the assignment and possibility to report the results with the help of a parent or other guardian. Each completed assignment was rewarded with a sticker.

The homework was related to the theme of the previous club session and the skills needed to complete the assignment had been learned previously in the club. One challenge of learning natural sciences is that the children and youth are not able apply the learned knowledge or skill if it is taken to a different context (Gilbert, 2006). In the homework, the children were encouraged to think about the phenomena presented during the club in new contexts. For example, after the first club session the children got their own pipettes to take home and an assignment to study how many drops of water can be fitted in one teaspoon. The assignment guided the children to think about the water theme of the upcoming club session.

The aim was also to encourage families to study the phenomena of mathematics and natural sciences together and motivate them to continue their mutual inquiry after the club. It has been noted that the parents' positive attitudes towards natural sciences and mathematics influence the children's interest and future choices (Smith \& Hausafus, 1997).

\section{Experiences from the pilot club}

At the end of the last club session, feedback on the club's aims and activities were gathered from both children and their guardians. All guardians $(\mathrm{N}=25)$ estimated that the goals of the clubs were reached very well. According to the feedback, the guardians felt that the club had increased their children's positive attitude and interest towards natural sciences and mathematics. Based on the feedback, the club had also supported the thinking and development of the children.

"This is the first hobby my son did not want to leave in the middle of," one father stated at the end of a club session.

Based on the feedback from the children, the characters played by the club guides proved to be a good model. Based on observations during the club, thanks to the characters the children got strong emotional experiences and were able to easily engage in the inquiries after the story. Based on verbal feedback from the parents, the children wanted to discuss about the club at home and often brought up the characters of the guides in the discussion. Also the songs, and their lyrics written especially for the club gave positive emotional experiences. In the upcoming science clubs the children will be encouraged to ask more questions to increase the joy of learning. 
Finland's Science Education Centre LUMA will continue the successful Pikku-J ipot club activities. In the next stage of the design research, the science club model will be developed based on the feedback and the effects of the club activities on children's thinking skills and questions they ask will be studied.

\section{References:}

Ainley, M., \&Ainley, J . (2011). Student engagement with science in early adolescence: The contribution of enjoyment to students' continuing interest in learning about science. Contemporary Educational Psychology, 36(1), 4-12.

Aksela, M. (1998). "Hei, minä uskallan ja osaan!"- Onnistumisen iloa ja elämyksiä luokanopettajiksi opiskelevien tiedekerhokoulutuksessa. In: Tuulta purjeisiin: Matemaattisten aineiden opetus 2000-luvulle, Jyväskylä, Atena Kustannus Oy.

Aksela, M. \& Mikkola, K. (1999). Kuinka luonnontieteitä voisi opettaa lapsille mukavalla ja motivoivalla tavalla?: Tiedekerhotoiminta innoittajana luokanopettajien peruskoulutuksessa. Diractia Varia (4): 2, 17- 48.

Aksela, M. (2008). The Finnish LUMA Centre: Supporting teachers and students in science, mathematics and technology for life-long learning. Lifelong Learning in Europe (13): 1, 70- 72.

Aksela, M. (2011). Tutkimuksellinen opiskelu osaksi luonnontieteiden opetusta. LUMA Sanomat: http:// www.luma.fi/ artikkelit/ tutkimuksellinen-opiskelu-osaksi-luonnontieteiden-opetusta. Read 23.3.2013.

Aksela, M. (2012). Tiedekasvatus ja sen tulevaisuus. Tieteessä tapahtuu (30): 4, 1- 2.

Allen, M. (2010). Learner error, affectual stimulation, and conceptual change. J ournal of Research in Science Teaching, 47, 151- 173.

Alexander, J . M., J ohnson, K. E., \& Kelley, K. (2012). Longitudinal analysis of the relations between opportunities to learn about science and the development of interests related to science. Science Education, 96(5), 763- 786.

Arinen P. \& Karjalainen T. (2007). PISA 2006 ensituloksia 15-vuotiaiden koululaisten luonnontieteiden, matematiikan ja lukemisen osaamisesta. Yliopistopaino Opetusministeriön julkaisuja 2007.

Bulunuz, M. (2012). Developing Turkish preservice preschool teachers' attitudes and understanding about teaching science through play. International J ournal of Environmental and Science Education, 7(2), 141- 166.

CASEL. What is SEL. http:// casel.org/ why-it-matters/ what-is-sel/ . Read 23.3.2013.

Chak, A. (2010). Adult response to children's exploratory behaviours: An exploratory study. Early Child Development and Care, 180, 633 - 646.

Cohen, J . 1999a. Social and emotional learning past and present: a psychoeducational dialoque. In J . Cohen (ed.) Educating minds and hearts. New York: Teachers College Press, 3- 23.

Durlak, J ., Weissberg, R. P., Dymnicki, A. B., Taylor, R. D., \& Schellinger, K. B. (2011). The Impact of Enhancing Students' Social and Emotional Learning: A Meta-Analysis of School-Based Universal Interventions. Child Development, 82(1), 405- 432.

El-Hindi, A. E. (2003). Integrating literacy and science in the classroom: From ecomysteries to readers theatre. Reading Teacher, 56(6), 536- 538.

European Commission. (2007). Science education now: A renewed pedagogy for the future of Europe. Brussels: European Commission Directorate-General for Research. http:/ / ec.europa.eu/research/science-society/ document_library/ pdf_06/report-rocard-onscience-education_en.pdf. Read 23.3.2013.

Gilbert, J . K. (2006). On the Nature of "Context" in Chemical Education. International J ournal of Science Education, 28(9), 957-976. 
Haynes, N. M., Ben-Avie, M., \&Ensign, J . (eds). (2003). How social and emotional development add up: Getting results in math and science education. New York: Teachers College Press.

Hidi, S., \&Ainley, M. (2002). Interest and adolescence. In F. Pajares \&T. Urdan (ed.), Academic motivation of adolescents (p. 247-275). Greenwich, CT. IAP.

Hidi, S., \& Harackiewicz, J . M. (2000). Motivating the academically unmotivated: A critical issue for the 21st century. Review of Educational Research, 70, 151- 179.

Hidi, S., \& Renninger, K. A. (2006). The four phase model of interest development. Educational Psychologist, 41, 111- 127.

National Research Counsil (2009). Learning Science in Informal Environments: People, Places and Pursuit. P. Bell, B. Lewenstein, A.W. Shouse and M.A. Feder (eds.) Washington D.C.: The National Academy Press

OECD (2010), PISA 2009 Results: What Students Know and Can Do - Student Performance in Reading, Mathematics and Science (Volume I) http:// dx.doi.org/ 10.1787/9789264091450-en

Pernaa, J . (2013). Kehittämistutkimus opetusalalla. Jyväskylä: PS-Kustannus.

Krapp, A. \& Prenzel, M. (2011). Research on interest in science: Theories, methods, and findings. International J ournal of Science Education, 33(1), 27- 50.

Kuenzi, J ., Matthews, C., \& Mangan, B. (2006). Science, technology, engineering, and mathematics (STEM) education issues and legislative options. Wahington, DC: Congressional Research Service, the Library of Congress.

Shriver, T., Schwab-Stone, M. \&DeFalco, K. 1999. Why SEL is the better way: the New Haven social development program. In J. Cohen (ed.) Educating minds and hearts. New York: Teachers College Press.

Smith, F. M., and Hausafus, C. O. (1997). Relationship of family support and ethnic minority students' achievement in science and mathematics. Science Education, 82, 111- 125.

Vartiainen, J . \&Aksela, M. (2012). LUMA Science Education Centre - J oy of Science for All, Bringing Science, Math and Technology Together. Niemi, H., Toom A. \& Kallioniemi A. Miracle of Education: The Principles and Practices of Teaching and Learning in Finnish Schools. Rotterdam: Sense Publishers.

Weare, K., Nind, M. (2011) Mental Health Promotion and problem Prevention in Schools: What Does the Evidence Say? Health Promotion International, 26 (SUPPL.1) 29- 69. 
